\title{
EVOLUTION OF EXPLOSIVE STRENGTH DATA IN YOUTH VOLLEYBALL PLAYERS BEFORE AND AFTER PANDEMIC
}

\author{
Francesca D’Eliaa $^{1 \mathrm{ACE}}$, Tiziana D’Isanto ${ }^{1 \mathrm{ABE}}$, Gaetano Altavilla ${ }^{1 \mathrm{ABCD}}$, Gaetano Raiola ${ }^{1 \mathrm{ADE}}$ \\ ${ }^{1}$ University of Salerno \\ Authors' Contribution: A - Study design; B - Data collection; C - Statistical analysis; D - Manuscript Preparation; E - Funds Collection
}

Corresponding Author: Gaetano Altavilla, E-mail: galtavilla@unisa.it

Accepted for Publication: November 30, 2021

Published: December 25, 2021

DOI: 10.17309/tmfv.2021.4.13

\begin{abstract}
Study purpose. This study aims to verify if there are significant differences and which type of correlation is between anthropometric and jumping ability variables by testing a group (elite) of Italian volleyball players (under 16), just after a month of training, applying a specific protocol.

Materials and methods. In all subjects, the following anthropometric and jumping ability parameters were assessed: height, weight, body mass index, height with a stretched arm (Reach1) and height with two extended arms (Reach2). The jumping ability was measured with the Squat jump (SJ) and Run-Up (RU) test. All data on anthropometric and jumping ability parameters were presented as mean and standard deviation (Mean $\pm \mathrm{SD}$ ).

Results. The results of the jumping ability parameters (Squat Jump and Run-Up) showed significant differences between treatment initial-final: Run-Up with $p=0.000$ and Squat Jump with $p=0.001$; and these showed a higher correlation, especially the variables linked to the ability to jump, evident differences compared to the initial period of treatment.

Conclusions. In high-level youth volleyball, the anthropometric and jumping ability profile is directly linked to the evaluation and continuous monitoring of physical qualities, and jumping ability becomes an important aspect for the control of performance.
\end{abstract}

Keywords: Jumping ability, testing, protocol training, performance.

\section{Introduction}

The SARS-CoV-2 pandemic has changed the habits of coaches and players during sports training and the management of stress and experience (Raiola, Aliberti, Esposito, Altavilla, D'Isanto \& D'Elia, 2020). There have been young players that abandoned the practice of training for poor motivation (Yanguas, Dominguez, Ferrer, Florit, Mourtabib \& Rodas, 2020). Others have used physical activity to manage the stress of the pandemic and who has managed their stress with food (Gallo, Gallo, Young, Moritz \& Akison, 2020). The scenario has changed at the beginning of 2020 (Altavilla, Macrì \& Esposito, 2021; D'Elia \& D'Isanto, 2021). The explosive strength in the final period of the pandemic (August 2021) was compared after one month of training (September 2021) using a specific protocol. Volleyball is classified as an activity with alternating aerobic and anaerobic engagement (Forte, Ceciliani, Izzo \& Altavilla, 2019) with a high percentage of body muscle mass and district demands for increased

(C) D’Elia, F., D’Isanto, T., Altavilla, G., \& Raiola, G., 2021. strength (D'Isanto, Di Tore \& Altavilla, 2018). The performance is characterized by technical gestures (jumps, attack shots, etc.) at high intensities (Ferrara, Fattore, Pignato \& D'isanto, 2019). Volleyball is a sport considered of attack (Raiola, Altavilla, De Luca \& Di Tore, 2016) with technical and physical characteristics, where the vertical jump is adopted (Forte, Ferrara \& Altavilla, 2019) generally aimed at increasing its effectiveness to obtain a winning action (D'Isanto, Altavilla \& Raiola, 2017). In modern volleyball, the use of the jump and the speed of play is a clear sign of greater demand for physical strength (Alminni, Altavilla, Scurati \& D'Elia, 2019) and the speed of the technical gesture. The explosive dynamic strength, the elevation, and the speed of displacement are selective and determining (Forte \& Altavilla, 2018), while physical demands during training or the match differ from each playing position (Altavilla, Di Tore, Riela \& D'Isanto, 2017). The main objective of athletic training and sports participation has always been to improve players' performance; therefore, the ability to jump together at the anthropometric parameters represents fundamentals quality in this type of sport (Aquino, Marra \& Altavilla, 
2019; Gabbett \& Georgieff, 2007). In most team sports, explosive strength is an important quality because it determines the quantity and quality of the athlete's movement. Furthermore, increasing or maintaining optimal strength levels is useful both for preventive and stabilization purposes and for performance purposes; the objectives and means in these cases vary greatly (Mencarelli, 2012). In this study, the anthropometric and explosive strength data relating to a male volleyball group (August 2021) have been analyzed, discussed and compared with the data of the same group collected after one month of training (September 2021).

The study purpose was to investigate whether this pandemic has negatively affected some physical skills, such as the explosive strength, of a group of young volleyball players, at the restart of workouts. It has been verified if there were significant differences and which type of correlation between anthropometric variables and jumping ability, just after one month of training, applying a specific protocol.

\section{Materials and methods}

\section{Study participants}

The sample of subjects included young male volleyball players $(\mathrm{n}=14)$, with an age (years) $=15.8 \pm 0.5$; height $(\mathrm{cm})=180.1$ \pm 6.5 ; weight $(\mathrm{kg})=74.4 \pm 6.0$ and $\mathrm{BMI}\left(\mathrm{kg} / \mathrm{m}^{2}\right)=22.9 \pm 0.2$. The players had at least four years of training experience and participated in the Italian volleyball Under-16 Championship (Elitè). For young volleyball players, the inclusion criteria considered was five years of training experience and participated on average 10 months training sessions. In contrast, the exclusion criteria were no history of injuries in the last year (i.e. muscles, tendons, bones).

\section{Study organization}

The variables investigated were: height $(\mathrm{cm})$; weight (kg); BMI $\left(\mathrm{kg} / \mathrm{m}^{2}\right)$; height with a stretched arm (Reach1, $\mathrm{cm}$ ); height with two extended arms (Reach2, $\mathrm{cm}$ ); Squat jump (SJ, cm) and Run-Up (RU, $\mathrm{cm}$ ). The tests were carried out in August before applying the training protocol. Subsequently, after having subjected all the group to the same training protocol 4 times a week for one month, the tests were carried out again. Each player simulated the attack actions with a Run-Up step (RU) and the Squat Jump (SJ). Three trials were performed for each test: only the best result was considered for the statistical analysis from the jumps performed. It was possible to calculate the different elevations obtained by the various players by jumping with and without run-up (Table 1). Other data has been obtained by evaluating the difference (Pre and Post protocol training) between the measurement of the attack action with a runup step and the maximum measure reached by extending the dominant arm (Reach1), between the squat jump action from a standstill and the maximum measure reached by completely extending the upper limbs (Reach2).

The method of detection and analysis of data required the use of the following tests and devices: the height in centimeters, the one-handed and two-handed reach, the maximum contact point of three squat Jumps performed in succession and the maximum contact point of three attack runs also performed in sequence were measured. One meter by hand with a millimeters rod was used to identify the contact points to collect the data. For measurement convenience, the athletes' fingers were made to moisten to identify and specify the height reached.

- One-hand reach: the athlete with the right side adhering to the wall (left for left-handers) and with the feet close and parallel extends the arm as high as possible on the marked wall.

- Two-handed reach: the athlete places his feet perpendicular to the wall, face facing the wall, extends his arms as high as possible on the marked wall, and the measurement is calculated on the maximum height reached by the lower hand.

- Squat Jump: consists of a vertical jump with feet together with the lower limbs bent with the hands at the hips. It is used to evaluate the ability to perform a concentric motion without countermovement. In the case of this group, the upper limbs are also used to obtain data as similar as possible to the technical objective of the wall.

- Run-up attack: is the specific technical gesture of volleyball that allows winning a point. It consists «in the succession of a step and a leap that culminates in the detachment position or of two steps and a leap». It is essential to know the athletes' heights to understand where they will hit the ball.

\section{Training protocol performed}

The activities always began with a joint mobilization session for the upper limbs using rubber bands and dynamic stretching for the lower limbs lasting 10 minutes. At the end of the activation session, a gentle warm-up of aerobic running was performed with an intensity not exceeding $60 \%$ for a maximum duration of 15 minutes to allow athletes to increase their body temperature and prepare their bodies for physical effort.

First week

- Strength exercises based on squats, bodyweight lunges with medium-high intensity and low recoveries (below $90 \mathrm{sec}$.) followed by push-ups on the upper limbs and work with elastic at the station.

- Speed exercises based on mixed sprints with different types of gaits. The distance covered was never greater than the total length of the field, i.e. 18 meters, in order to remain in an anaerobic alactacid metabolism.

- Exercise of jumping recalling attack and block techniques with medium recoveries without tiring them too much.

- The training session ended with a 5-minute relaxing run at a slow pace, followed by a strengthening session of the abdominal core and closed by a static stretching session.

Second week

- Strength exercises based on combinations of lunges, squat jumps and attack run performed in succession. The repetitions were high and the recoveries set below $60 \mathrm{sec}$.

- Mixed speed exercises that are combined with lateral movements, jumps and dips.

- Normal jumping exercises combined with attack runs in conditions of physical and psychological stress. 
Third week

- Very intense speed exercises with very short recoveries $(30 \mathrm{sec})$

- Strength exercises for the lower limbs with station circuits consisting of: Push-ups on the lower limbs with a barbell, Lunges with dumbbells, Bulgarian squat, Step up and a squat jump.

- Strength exercises for the upper limbs performed in the gym were characterized by low repetitions and a number of series between 5-6. The percentage of the load fluctuated between 60 and $80 \%$ of the ceiling. The recovery was around $60 \mathrm{sec}$. The exercises used were: pectorals on a flat bench and cable crosses, Lat machine and rowing machine, biceps flexion with dumbbells and barbell, Push Down with rope and French Press, Push up and Front Raises.

Fourth week

- Strength exercises for the lower limbs in the gym are characterized by an average number of repetitions and a number of sets between 5-6. The percentage of the load fluctuated between 70 and $80 \%$ of the ceiling. The recovery was 60 seconds. The exercises used were: Dumbbell Lunges, Barbell Squats, Leg Press, Leg Curl and Leg Extension and Weighted Squat Jumps, Deadlifts.

- Strength exercises for the upper limbs performed with station circuits consisting of Push-ups on the arms, throwing a medicine ball to the partner or on a mat. Biceps and back curls with elastic bands.

- Jumping exercises with the impact method based on a few series and a high number of repetitions (greater than 12): jumps upwards followed by 3 running steps, jump forward and subsequent high jump; Push-ups on the lower limbs, 3 running steps, jump forward and subsequent jump upwards; jump down from a height of $50 \mathrm{~cm}$, run 2-3 steps, jump forward and then jump upwards.

Fifth week

- Insertion of technical work with specific analytical and synthetic exercises on all the fundamentals.

- Continuation of the plyometric work based on: jumps down from a height of $0.70 \mathrm{~cm}, 2-3$ running steps, jump forward and subsequent jump upwards; push-ups on the lower limbs, high jump, low jump and attack run with deadlift; continuous sequence of high jumps and consecutive low jumps.

\section{Statistical analysis}

All data were presented as mean and standard deviation (Mean \pm SD). Before the parametric analysis, the normality of data distribution was verified by the using Shapiro-Wilk test. A Test-t for paired samples was conducted to check the differences between pre and post jumping ability variables, while the homogeneity of variances was checked with Levene's test. The correlations between all the variables considered were calculated using the Pearson correlation coefficient. Type I error was set at $\alpha=5 \%$, and all statistical analyses were performed with the software IBM SPSS Statistics 23.

\section{Results}

Table 1 shows the mean and standard deviation of the anthropometric values and the jumping ability of all the volleyball players considered. Furthermore, differences between RU-Reach1 (43.2 - 50.5 = + 7.3) and SJ-Reach2 (22.9 $-29.8=+6.9$ ) show evident levels of improvement, between the first and the second training period.

The comparison (Pre and Post) of the anthropometric parameters and the jumping ability are shown in table 2 .

Table 1. Anthropometric and jumping ability values of all players

\begin{tabular}{lcc}
\hline \multicolumn{1}{c}{ Variables } & $\begin{array}{c}\text { Mean } \pm \text { SD (N=14) August } \\
\text { (pre-training) }\end{array}$ & $\begin{array}{c}\text { Mean } \pm \text { SD (N=14) September } \\
\text { (post-training) }\end{array}$ \\
\hline Age (years) & $15.8 \pm 0.5$ & $15.8 \pm 0.5$ \\
Height $(\mathrm{cm})$ & $180.1 \pm 6.5$ & $180.1 \pm 6.5$ \\
Weight $(\mathrm{kg})$ & $74.4 \pm 6.0$ & $74.4 \pm 6.0$ \\
BMI $\left(\mathrm{kg} / \mathrm{m}^{2}\right)$ & $22.9 \pm 0.2$ & $22.9 \pm 0.2$ \\
Reach1 $(\mathrm{cm})$ & $238.4 \pm 7.8$ & $238.4 \pm 7.8$ \\
Reach2 $(\mathrm{cm})$ & $233.4 \pm 6.9$ & $233.4 \pm 6.9$ \\
Squat Jump $(\mathrm{cm})$ & $256.3 \pm 21.7$ & $263,2 \pm 19.6$ \\
Run-Up $(\mathrm{cm})$ & $281.6 \pm 18.0$ & $288,9 \pm 16.8$ \\
Differences between RU-Reach1 & $281.6-238.4=+43.2$ & $288.9-238.4=+50.5$ \\
Differences between SJ-Reach2 & $256.3-233.4=+22.9$ & $263.2-233.4=+29.8$ \\
\hline
\end{tabular}

Table 2. Test-t for paired samples on the Run-Up and Squat Jump (treatment pre-post)

\begin{tabular}{|c|c|c|c|c|c|c|c|c|}
\hline \multirow[t]{2}{*}{ Indicators } & \multirow[t]{2}{*}{ Average } & \multirow[t]{2}{*}{ Std. dev. } & \multirow{2}{*}{$\begin{array}{c}\text { Average } \\
\text { standard } \\
\text { error }\end{array}$} & \multicolumn{2}{|c|}{$\begin{array}{l}\text { 95\% confidence interval } \\
\text { difference }\end{array}$} & \multirow[t]{2}{*}{$\mathbf{t}$} & \multirow[t]{2}{*}{ df } & \multirow{2}{*}{$\mathbf{p}$} \\
\hline & & & & Lower & Higher & & & \\
\hline RU Pre - RU Post & $-6,857$ & 4,655 & 1,244 & $-9,544$ & $-4,169$ & $-5,512$ & 13 & 0.000 \\
\hline SJ Pre - SJ Post & $-6,857$ & 5,829 & 1,557 & $-10,22$ & $-3,491$ & $-4,402$ & 13 & 0.001 \\
\hline
\end{tabular}


Table 3. Correlation matrix: anthropometric and jump ability (Pre and Post training)

\begin{tabular}{|c|c|c|c|c|c|c|c|c|c|c|c|c|c|}
\hline PRE & Height & Weight & Reach 1 & Reach 2 & Run-Up & $\begin{array}{l}\text { Squat } \\
\text { Jump }\end{array}$ & POST & Height & Weight & Reach 1 & Reach 2 & Run-Up & $\begin{array}{l}\text { Squat } \\
\text { Jump }\end{array}$ \\
\hline Height & - & & & & & & Height & - & & & & & \\
\hline Weight & 0.996 & - & & & & & Weight & 0.996 & - & & & & \\
\hline Reach 1 & 0.931 & 0.936 & - & & & & Reach 1 & 0.931 & 0.936 & - & & & \\
\hline Reach 2 & 0.834 & 0.860 & 0.948 & - & & & Reach 2 & 0.834 & 0.860 & 0.948 & - & & \\
\hline Run-Up & 0.905 & 0.919 & 0.889 & 0.810 & - & & Run-Up & 0.923 & 0.943 & 0.961 & 0.928 & - & \\
\hline $\begin{array}{l}\text { Squat } \\
\text { Jump }\end{array}$ & 0.901 & 0.910 & 0.936 & 0.867 & 0.985 & - & $\begin{array}{l}\text { Squat } \\
\text { Jump }\end{array}$ & 0.906 & 0.917 & 0.981 & 0.959 & 0.987 & \\
\hline
\end{tabular}

To detect the differences between the several variables considered, a Test-t for paired samples was used in the initial and final period. The results of this comparison, between pre and post training, on the jumping ability variables considered (Run-Up and Squat Jump) shown significant differences: RU $(\mathrm{t}=-5.512 ; \mathrm{p}=0.000)$ and $\mathrm{SJ}(\mathrm{t}=-4,402, \mathrm{p}=0.001)$.

The results of the correlation matrix of the different variables considered are shown in table 3 . The correlations between the variables related to jumping ability show further improvements, while the other variables anthropometric are the same or almost the same in terms of correlation.

\section{Discussion}

From the statistical analysis of results, we can say that the group considered $(n=14)$ recorded better values regarding the values of ability jumping, after a period of training, following a specific protocol. These analyses show that different elements such as the arm length, the push of the arms in the attack and block jumps, the strength developed by the lower limbs, the use of an effective run-up in the jump phase and the coordination between the movements of the arms and legs, can be decisive for having talented players. After the specific training ( 5 weeks period), the correlations between the variables related to jumping ability show further improvements, while the other variables are the same or almost the same in terms of correlation. The high correlation between RU and the other variables could indicate an athlete's ability to transform the accumulated kinetic energy during the run-up phase into potential energy. The correct identification of the morphological characteristics and the close connection of these with the technical role becomes decisive for obtaining excellent results. These results confirm the link between the morphological characteristics, the orientation towards specialization and the training of muscular qualities (Sands, Smith, Kivi, McNeal, Dorman, Stone \& Cormieet, 2005). These qualities result be fundamental for the development and the choice of the player of talent. Finally, in agreement with the findings in the literature, a study by Sheppard et al., (2008) examined the potential strength, power, and anthropometric contributors to vertical jump performances that are considered specific to volleyball success. Another study by Aouadi et al. (2012) showed that age, weight, standing height, and fat-free mass were the predictors of jumping performance. Thus, measuring anthropometric characteristics, such as stature and lower limb length, may assist coaches in the early phases of talent identification in volleyball. The results may help in verifying the effectiveness of a specific training program and detecting highly talented athletes. This study presents a limited sample. Instead, it could come to stronger conclusions with a much more wide sample. Finally, future research might be to repeat the study on a female sample and then compare the data obtained with the male sample to detect performance and abilities differences in quantitative and qualitative terms.

\section{Conclusions}

After a pandemic period in which training was scarce or autonomous, the resumption of scheduled and monitored workouts showed significant jumping performance differences. The results show significant differences between the two periods (Pre and Post training), mainly in jumping ability. In modern volleyball, due to the reduced duration of the game and the greater intensity of the rhythm; therefore, we increasingly need tall, fast and powerful athletes. The evaluation, training, and continuous monitoring of physical qualities and jumping ability are important for controlling performance and selecting talented players. In high-level youth volleyball, the anthropometric and ability jump profile is directly linked to the evaluation and continuous monitoring of physical qualities and jumping ability become an essential aspect for the control of performance.

\section{Conflict of interest}

The authors declare that they have no conflict of interest.

\section{References}

Raiola, G., Aliberti, S., Esposito, G., Altavilla, G., D'Isanto, T., \& D'Elia, F. (2020). How has the practice of physical activity changed during the covid-19 quarantine? a preliminary survey. Teorîa ta Metodika Fizičnogo Vihovannâ, 20(4), 242-247. https://doi.org/10.17309/tmfv.2020.4.07

Yanguas, X., Dominguez, D., Ferrer, E., Florit, D., Mourtabib, Y., \& Rodas, G. (2020). Returning to Sport during the Covid-19 pandemic: The sports physicians' role. Apunts Sports Medicine, 55(206), 49.

https://doi.org/10.1016/j.apunsm.2020.06.001 
Gallo, L. A., Gallo, T. F., Young, S. L., Moritz, K. M., \& Akison, L. K. (2020). The impact of isolation measures due to COVID-19 on energy intake and physical activity levels in Australian university students. Nutrients, 12(6), 1865. https://doi.org/10.3390/nu12061865

Altavilla, G., Macrì, I., \& Esposito, G. (2021). Data collection on indoor and outdoor physical activities during the SARS-Covid-2 pandemic. Journal of Physical Education and Sport, 21(Suppl.1), 686-691.

https://doi.org/10.7752/jpes.2021.s1083

D'Elia, F., \& D’Isanto, T. (2021). Outdoor movement education in primary school during COVID-19 pandemic in the synthetic perceptions of primary school university training student. Journal of Human Sport and Exercise, 16(3), 15221537. https://doi.org/10.14198/jhse.2021.16.proc3.68

Forte, D., Ceciliani, A., Izzo, R., \& Altavilla, G. (2019). Transition period: Pilot study on performance reduction of ability to jump in volleyball. Journal of Human Sport and Exercise, 14 (2), S221-S227.

https://doi.org/10.14198/jhse.2019.14.proc2.09

D'Isanto, T., Di Tore, P., \& Altavilla, G. (2018). Correlation of the anthropometric characteristics and the ability to jump in volleyball. Journal of Human Sport and Exercise, 13(2), S393-S400. https://doi.org/10.14198/jhse.2018.13.proc2.23

Ferrara, F., Fattore, S., Pignato, S., \& D’Isanto, T. (2019). An integrated mode to assess service volleyball among power glove, video analysis and testing. Journal of Human Sport and Exercise, 14(4), S739-S745.

Raiola, G., Altavilla, G., De Luca, C., \& Di Tore, P.A. (2016). Analysis on some aspects of the service in volleyball. Sport Science, 9(1),74-77.

Forte, D., Ferrara, F., \& Altavilla, G. (2019). Relationship between types of stretching and jumping in volleyball. Journal of Physical Education and Sport, 19(S5), 18591862. https://doi.org/10.7752/jpes.2019.s5275

D’Isanto, T., Altavilla, G., Raiola, G. (2017). Volleyball Service Teaching Method: Intensive and Extensive Tools in Cognitive and Ecological Approach. Journal of Physical Education and Sport, 17(Suppl. 5), 2222-2227. https://doi.org/10.7752/jpes.2017.s5233

Alminni, C., Altavilla, G., Scurati, R., \& D’Elia, F. (2019). Effects induced through the use of physical and motor tests in volleyball. Journal of Human Sport and Exercise - 2019

- Spring Conferences of Sports Science. Journal of Human Sport and Exercise - 2019 - Spring Conferences of Sports Science. https://doi.org/10.14198/jhse.2019.14.Proc4.20

Forte, D., \& Altavilla, G. (2018). Preliminary correlation between anthropometric and performance data in volleyball about the transition period. Journal of Physical Education and Sport, 18(s5), 1994-1998. https://doi.org/10.7752/jpes.2018.s5296

Altavilla, G., Di Tore, P.A., Riela, L., D’Isanto, T. (2017). Anthropometric, physiological and performance aspects that differentiate male athletes from females and practical consequences. Journal of Physical Education and Sport, 17(s5), 2183-2187. https://doi.org/10.7752/jpes.2017.s5226

Aquino, M., Marra, F., \& Altavilla, G. (2019). Study on the physical capacity in the individual roles of basic competitive volleyball. Journal of Physical Education and Sport, 19(Suppl.5), 1788-1795. https://doi.org/10.7752/jpes.2019.s5263

Gabbett, T., \& Georgieff, B. (2007). Physiological and anthropometric characteristics of junior national, state, and novice volleyball players. J. Strength Cond Res, 21(3), 902-908. https://doi.org/10.1519/r-20616.1

Mencarelli, M. (2012). Le guide della pallavolo. Manuale allievo allenatore primo livello giovanile. Calzetti \& Mariucci.

Sands, W.A., Smith, L.S., Kivi, D.M., McNeal, J.R., Dorman, J.C., Stone, M.H., \& Cormieet, P. (2005). Anthropometric and physical abilities profiles: US National Skeleton Team. Sports Biomech., 4(2),197-214. https://doi.org/10.1080/14763140508522863

Sheppard, J.M., Cronin, J.B., Gabbett, T.J., McGuigan, M.R., Etxebarria, N., \& Newton, R.U. (2008). Relative importance of strength, power, and anthropometric measures to jump performance of elite volleyball players. J. Strength Cond Res, 22(3), 758-765. https://doi.org/10.1519/jsc.0b013e31816a8440

Aouadi, R., Jlid, M. C., Khalifa, R., Hermassi, S., Chelly, M. S., Van Den Tillaar, R., Gabbett, T. (2012). Association of anthropometric qualities with vertical jump performance in elite male volleyball players. The Journal of sports medicine and physical fitness, 52(1), 11-17.

\title{
ЗМІНИ ДАНИХ ПРО ВИБУХОВУ СИЛУ У ЮНИХ ВОЛЕЙБОЛІСТІВ ДО ТА ПІСЛЯ ПАНДЕМІї
}

\author{
Франческа Д’Еліа ${ }^{1 \mathrm{ACE}}$, Тіціана Д’Ізанто ${ }^{\mathrm{AbE}}$, Гаетано Альтавілла ${ }^{1 \mathrm{ABCD}}$, Гаетано Райола ${ }^{1 \mathrm{AДЕ}}$ \\ ${ }^{1}$ Університет Салерно \\ Авторський вклад: А - дизайн дослідження; В - збір даних; C - статаналіз; D - підготовка рукопису; Е - збір коштів \\ Реферат. Стаття: 7 с., 3 табл., 20 джерел.
}

Мета дослідження - перевірити наявність значних відмінностей та визначити тип кореляції між антропометричними та стрибковими змінними шляхом тестування групи (професійний рівень) італійських волейболістів (до 16 років) одразу після місяця тренувань із застосуванням спеціального протоколу.

Матеріали та методи. У всіх досліджуваних оцінювали такі антропометричні та стрибкові параметри: зріст, 
вага, індекс маси тіла, зріст з витягнутою рукою (Reach1) та зріст з двома витягнутими руками (Reach2). Здатність до стрибків вимірювалася за допомогою тестів «Присідання з вистрибом» (ПВ) та «Розбіг» (Р). Усі дані про антропометричні та стрибкові параметри були представлені як середнє значення та стандартне відхилення (середнє значення \pm SD).

Результати. Результати стрибкових параметрів (присідання з вистрибом та розбіг) показали значні відмінності між початковими та фінальними даними: розбіг $(\mathrm{p}=0,000)$ та присідання з вистрибом ( $=0,001)$; вони також показа- ли вищу кореляцію, особливо змінні, пов'язані зі здатністю стрибати, що є очевидними відмінностями порівняно з початковим періодом дослідження.

Висновки. У професійному юнацькому волейболі антропометричний та стрибковий профіль безпосередньо пов'язаний з оцінкою та безперервним моніторингом фізичних якостей, а стрибкові здібності стають важливим аспектом для контролю ефективності.

Ключові слова: стрибкові здібності, тестування, протокольне навчання, ефективність.

\section{Information about the authors:}

D’Elia Francesca: fdelia@unisa.it; https://orcid.org/0000-0003-1441-8101; Department of Human, Philosophical and Education Sciences, University of Salerno. Via Giovanni Paolo II, 132 - 84084 Fisciano (SA), Italy.

D’Isanto Tiziana: tdisanto@unisa.it ; https://orcid.org/0000-0001-7151-7486; Department of Human, Philosophical and Education Sciences, University of Salerno. Via Giovanni Paolo II, 132 - 84084 Fisciano (SA), Italy.

Altavill Gaetano: galtavilla@unisa.it; https://orcid.org/0000-0001-8436-7819; Department of Political and Social studies, University of Salerno. Via Giovanni Paolo II, 132 - 84084 Fisciano (SA), Italy.

Raiola Gaetano: graiola@unisa.it; https://orcid.org/0000-0002-7659-1674; Department of Political and Social studies, University of Salerno. Via Giovanni Paolo II, 132 - 84084 Fisciano (SA), Italy.

Cite this article as: D’Elia, F., D’Isanto, T., Altavilla, G., \& Raiola, G. (2021). Evolution of Explosive Strength Data in Youth Volleyball Players Before and After Pandemic. Teoriâ ta Metodika Fizičnogo Vihovannâ, 21(4), 375-380.

https://doi.org/10.17309/tmfv.2021.4.13

Received: 15.11.2021. Accepted: 30.11.2021. Published: 25.12.2021

This work is licensed under a Creative Commons Attribution 4.0 International License (http://creativecommons.org/licenses/by/4.0). 